\title{
PENERAPAN MODUL INVENTOR DENGAN PENDEKATAN CTL UNTUK MENINGKATKAN KOMPETENSI SISWA PADA MATA DIKLAT CAD
}

\author{
Muhammad Syari'ati Ramadhani ${ }^{1}$, Yatin Ngadiyono ${ }^{2}$ \\ 1,2 Jurusan Pendidikan Teknik Mesin FT UNY \\ edward.newgate.x@gmail.com
}

\begin{abstract}
The purpose of this study was to determine an applicable framework of CTL learning approaches and improving the competence of students using module as media. This research is a class action research comprising of three cycles. Subjects of this study were students of class XI machining TP 1 at SMK Muhammadiyah 1 Bantul, with 26 students as respondents. The result of this study is a learning framework for CAD with CTL approach. The sequence of this framework are: directing the use of the module and the materials selection, the formation of discussion groups based on students' computer skills, providing motivation and samples of CAD drawings used in the industry, providing drawing jobs that challenge students' knowledge, doing the drawing exercise within the group using the module as a knowledge source, groups discussion to find solutions to the problems, debriefing and reflection, and finally implementing an authentic assessment. Students' competence has increased from the average value of 62.16 and $0 \%$ passed the test in the first cycle, to 82.69 and $84.62 \%$ passed in the second cycle, and to 80.68 with $100 \%$ passed in the last cycle.
\end{abstract}

Keywords: computer aided drawing design, contextual teaching and learning, competency

\begin{abstract}
ABSTRAK
Tujuan dari penelitian ini adalah untuk mengetahui kerangka pendekatan pembelajaran CTL yang dapat diterapkan dan peningkatan kompetensi siswa dengan media modul. Penelitian ini merupakan penelitian tindakan kelas yang terdiri dari tiga siklus. Subjek dari penelitian ini adalah siswa pemesinan kelas XI TP 1 SMK Muhammadiyah 1 Bantul dengan jumlah responden sebanyak 26 siswa. Hasil penelitian menghasilkan kerangka pembelajaran CAD dengan pendekatan CTL dengan urutan pertama pengarahan penggunaan modul dan penentuan materi, pembentukan kelompok diskusi sesuai dengan keahlian siswa, memberikan motivasi dan contoh pekerjaan CAD di industri, pemberian soal yang menantang pengetahuan siswa, mengerjakan latihan bersama kelompok dengan sumber pengetahuan dari modul, diskusi kelompok untuk menemukan solusi masalah, tanya jawab dan refleksi, dan terakhir melaksanakan penilaian autentik. Kompetensi siswa mengalami peningkatan rata-rata nilai dari siklus pertama 62.16 kelulusan $0 \%$ ke siklus dua menjadi 82.69 kelulusan $84.62 \%$ kemudian siklus terakhir menjadi 80.68 kelulusan $100 \%$.
\end{abstract}

Kata kunci: CAD, CTL, kompetensi

\section{PENDAHULUAN}

Perkembangan teknologi menyebabkan terjadi perubahan penting pada kehidupan sosial masyarakat. Perubahan tersebut dapat dijumpai dalam berbagai bidang pekerjaan, utamanya yang yang dahulu menggunakan proses manual kemudian menjadi otomatis atau digital. Perubahan tersebut mempengaruhi tuntutan kompetensi dan keterampilan kerja di berbagai bidang pekerjaan untuk menghasilkan produk yang berkualitas.
Salah satu pekerjaan yang mengalami perubahan adalah gambar teknik mesin. Proses menggambar teknik yang dahulu menggunakan alat-alat tangan seperti pensil atau rapido, penggaris, dan penghapus sekarang telah banyak tergantikan oleh proses menggunakan komputer. Kompetensi untuk menggunakan komputer sebagai media menggambar teknik disebut Computer Aided Drawing (CAD).

CAD adalah proses menggambar dengan komputer menggunakan software khusus CAD 
untuk membantu proses desain dan pembuatan gambar (David A. Madsen \& David P. Madsen, 2012). Penggunaan CAD dalam proses desain dan pembuatan gambar teknik telah membuat pekerjaan tersebut semakin akurat dan cepat. Kecanggihannya CAD dapat menyalurkan lebih banyak kreativitas dari para desainer agar lebih produktif dalam mengembangkan ide. CAD bahkan mampu membuat sebuah gambar arsitektur yang mana terdapat unsur seni didalamnya.

Selama ini pembelajaran CAD yang ada di SMK tersebut belum menjadi pusat perhatian untuk dikembangkan. Hal ini menyebabkan kompetensi siswa dalam bidang CAD masih rendah. Keahlian yang dikuasai oleh siswa hanya CAD 2 dimensi, itupun tanpa adanya pengetahuan dasar yang lengkap mengenai CAD.

Xin-Ran Duan (2004) dari Ivy Tech Community College of Indiana dalam hasil penelitiannya menjelaskan bahwa keahlian yang dibutuhkan pada kompetensi CAD menyebutkan beberapa keahlian yang harus dikuasai sebagai berikut: (1) Pengetahuan umum tentang software CAD; (2) CAD 2D drawing; (3) CAD 3D modeling; (4) Pemrograman dasar CAD; (5) CAD design project; (6) Pengaturan dalam software CAD. Dari sejumlah keahlian tersebut yang paling utama dibutuhkan oleh industri adalah pengetahuan umum software CAD, CAD 2D drawing, dan CAD 3D modeling. Ketiga keahlian tersebut menempati posisi atas dari survei yang dilakukan peneliti di perusahaan.

Gambaran mengenai keahlian dalam kompetensi CAD di SMK dengan yang harus dikuasai untuk menempati posisi drafter atau desainer, terlihat bahwa keahlian dalam kompetensi CAD yang dikuasai siswa SMK masih belum mencukupi kebutuhan. Agar siswa dapat masuk dalam bidang kerja CAD setelah lulus nantiya, tentu kekurangan tersebut harus segera diatasi. Oleh karena itu, perlu adanya perubahan dalam pembelajaran CAD yang sudah ada agar keahlian dalam kompetensi $\mathrm{CAD}$ yang harus dikuasai dapat terpenuhi.
Selama ini pembelajaran di SMK masih terpusat pada guru sehingga pengetahuan dan keterampilan siswa kurang berkembang secara maksimal. Pengetahuan dan keterampilan yang didapat siswa hanya sebatas apa yang telah diajarkan oleh guru. Hal ini yang menyebabkan kurangnya inisiatif dan keberanian siswa untuk melakukan eksplorasi secara mandiri, sehingga kemampuan siswa menjadi terbatasi.

Selain masalah pembelajaran, media yang digunakan guru terkadang tidak mudah dijangkau oleh siswa. Beberapa contohnya adalah guru sering hanya menggunakan media power point atau penulisan teks dipapan tulis. Dengan media tersebut tugas guru memang menjadi lebih mudah, namun materi yang disampaikan hanya dapat dijangkau siswa saat ditampilkan. Guru seharusnya menggunakan media yang mudah dijangkau siswa baik saat belajar didalam kelas maupun saat dirumah.

Pembelajaran pada mata diklat CAD agar lebih efektif dan efisien harus ada media yang dapat digunakan oleh siswa secara individu. Sedangkan pembelajaran di kelas harus dirubah sedemikian rupa sehingga guru hanya berperan sebagai pemandu siswa belajar, bukan sebagai pusat dari pembelajaran, maka pembelajaran CAD akan lebih efektif dan efisien untuk mengembangkan kemampuan siswa.

Sharon E. Smaldino (2011:279) menerangkan bahwa modul merupakan unit pengajaran yang lengkap yang dirancang untuk digunakan oleh seorang pemelajar atau sekelompok kecil pemelajar tanpa kehadiran guru. Dalam pengertian ini modul dirancang dengan tujuan untuk digunakan belajar secara individu. Oleh karena itu modul harus dibuat interaktif, lengkap dan terprogram agar pemelajar tidak bingung saat menggunakannya.

Johnson (2014) menerjemahkan CTL atau Contextual Teaching and Learning sebagai suatu sistem pembelajaran yang membantu siswa menemukan makna dalam pelajaran dengan cara menghubungkan materi akademik dengan konteks kehidupan keseharian mereka. Dalam pembelajaran kontekstual guru berperan sebagai fasilitator tanpa henti (reinforcing), 
yakni membantu siswa menemukan makna dari pengetahuan yang dipelajari oleh siswa. Siswa membuat hubungan-hubungan penting yang menghasilkan makna dengan melaksanakan pembelajaran yang diatur sendiri, bekerja sama, berpikir kritis dan kreatif, menghargai orang lain, mencapai standar tinggi, dan berperan serta pada tugas-tugas yang diberikan.

Akhmad Adib Setyawan menunjukkan bahwa ada peningkatan aktivitas siswa dengan penggunaan metode pembelajaran Contextual Teaching and Learning (CTL) pada mata pelajaran Gambar Teknik Mesin. Terlihat dari persentase aktivitas siswa pada siklus I sebesar $67,59 \%$ (cukup) meningkat $9,72 \%$ pada siklus II menjadi $77,31 \%$ (baik) dan meningkat 9,26\% pada siklus III menjadi $86,57 \%$ (sangat baik). Dionysius Dwi Noviantoro (2014) menunjukkan peningkatan aktivitas siswa dengan penggunaan metode CTL pada mata pelajaran Membaca Gambar Teknik. Terlihat dari persentase aktivitas siswa pada siklus I sebesar $60,87 \%$ (cukup) meningkat menjadi $76,09 \%$ (baik) pada siklus II dan meningkat menjadi $86,41 \%$ (sangat baik) pada siklus III. Hasil penelitian juga menunjukkan ada peningkatan prestasi belajar yang terlihat dari rata-rata nilai hasil tes. Nilai tes 56,52 pada siklus I meningkat menjadi 63,04 di siklus II dan meningkat pada siklus III yaitu menjadi 73,04.

Penelitian ini bertujuan mengetahui peningkatan kompetensi siswa pada mata diklat CAD dengan menerapkan modul dengan pendekatan CTL dan untuk mengetahui bentuk pendekatan yang paling efektif untuk meningkatkan kompetensi siswa pada mata diklat CAD.

\section{METODE}

Penelitian ini merupakan penelitian tindakan kelas (PTK) atau sering disebut classroom action research. Suharsimi (2015) menjelaskan bahwa PTK adalah penelitian yang memaparkan proses dan hasil dari tindakan yang diterapkan oleh peneliti untuk meningkatkan kualitas pembelajaran di kelas. Fokus penelitian ini adalah untuk meningkatkan kompetensi siswa pada mata diklat CAD dengan penerapan modul diikuti dengan pendekatan CTL guna memperbaiki kualitas pembelajaran di kelas. Subjek dari penelitian adalah siswa Teknik Pemesinan kelas XI TP 1 SMK Muhammadiyah 1 bantul dengan jumlah responden 26 siswa. Pemilihan subjek dilakukan dengan wawancara kepada guru pembelajaran terkait sebelum dilaksanakan penelitian.

Pada penelitian ini digunakan model PTK dari Kemmis dan Mc Tagart. Dalam desain model ini, satu fokus tindakan (action) merupakan satu siklus tindakan yang terdiri dari beberapa langkah tindakan pembelajaran. Satu materi pokok terdiri dari beberapa materi yang diselesaikan dalam beberapa kali tindakan. Pada satu siklus dalam PTK terdapat 4 fase atau tahapan yaitu perencanaan (Plan), tindakan (Act), pengamatan (Observe), dan refleksi (Reflect).

Pengumpulan data menggunakan pengamatan, penilaian pekerjaan siswa, rekaman video proses pembelajaran, dan dokumentasi. Pengamatan untuk melihat aspek afektif dari siswa dan kinerja guru, dengan menggunakan lembar observasi yang telah disiapkan. Penilaian pekerjaan siswa dilakukan sebagai sumber data aspek kognitif dan psikomotor siswa. Rekaman video digunakan sebagai bukti tambahan pada pelaksanaan penelitian dan juga sebagai penguat data tertulis yang telah diambil pada proses penelitian. Selain itu rekaman video juga dapat digunakan sebagai evaluasi bagi pengajar sehingga dapat melihat sendiri proses pembelajaran yang telah dilakukannya. Dokumentasi digunakan untuk megumpulkan data secara tidak langsung kepada subjek penelitian pada saat pembelajaran berlangsung.

\section{HASIL DAN PEMBAHASAN}

Pada proses belajar mengajar yang telah dilaksanakan, siswa diberikan kesempatan untuk mengeksplorasi sendiri pengetahuan 
mengenai software inventor. Kegiatan eksplorasi didapatkan hasil bahwa siswa tidak mampu mengekplorasi pengetahuan secara mandiri dan masih sangat tergantung pada penjelasan guru. Siswa dalam melakukan eksplorasi merasa takut jika melakukan kesalahan dan mengakibatkan kerusakan pada software atau hardware komputer sehingga tidak berani mengambil tindakan percobaan. Diskusi siswa pada kegiatan pra siklus belum banyak dilakukan, karena siswa masih sangat awam dengan software Inventor sehingga bingung akan hal yang akan didiskusikan. Dari beberapa kejadian tersebut dapat disimpulkan bahwa keaktifan siswa dalam pembelajaran masih kurang.

Selain kurangnya keaktifan siswa dalam pembelajaran, pengetahuan siswa mengenai CAD masih sangat rendah. Namun hal ini dapat dimaklumi dikarenakan pembelajaran CAD memang baru diberikan di kelas XI, sehingga pada saat penelitian dilaksanakan siswa baru memahami sedikit tentang CAD. Pemahaman dasar siswa yang belum begitu mendalam karena baru mengawali pembelajaran CAD ini justru memberikan kesempatan kepada peneliti untuk membentuk pengetahuan dasar siswa yang matang agar lebih mudah dikembangkan kedepannya.

Modul dengan pendekatan CTL guna meningkatkan kompetensi siswa. Pada siklus I digunakan langkah pembelajaran berikut: (a) penentuan kompetensi yang akan dicapai dan materi; (b) pemberian motivasi dan contoh pekerjaan CAD di industri; (c) pemberian soal latihan sebagai penggali pengetahuan awal siswa; (d) mengerjakan latihan secara individu dengan bantuan modul; (e) penerapan diskusi terbuka dalam proses pengerjaan; (f) melakukan penarikan kesimpulan dari diskusi terbuka guna memecahkan masalah; (g) membuka sesi tanya jawab dan penyampaian permasalahan dan solusi; (h) melaksanakan penilaian autentik. Pengamatan hasil pekerjaan siswa, didapati bahwa siswa masih kesulitan menyerap pengetahuan dengan sistem belajar modul. Hal ini dibuktikan dengan nilai pekerjaan siswa yang masih sangat rendah. Mempelajari keahlian CAD yang mana merupakan pengetahuan baru bagi siswa dengan pendekatan baru sepertinya membuat siswa sedikit kesulitan dalam menyerap pelajaran. Hasil penilaian pekerjaaan siswa dapat dilihat pada Tabel 1.

Tabel 1. Hasil Penilaian Pekerjaan Siswa Siklus I

\begin{tabular}{|c|c|c|c|}
\hline \multirow[b]{2}{*}{ Nilai } & \multicolumn{3}{|c|}{ Frekuensi } \\
\hline & $\begin{array}{c}\text { Modifikas } \\
\text { i Model } \\
\text { 3D } \\
\end{array}$ & $\begin{array}{c}\text { Penyajian } \\
\text { Gambar } \\
\text { 2D } \\
\end{array}$ & $\begin{array}{l}\text { Kompetensi } \\
\text { CAD }\end{array}$ \\
\hline$\leq 60$ & 7 & 15 & 10 \\
\hline $61-65$ & 16 & 8 & 11 \\
\hline $66-70$ & 0 & 1 & 2 \\
\hline $71-75$ & 0 & 1 & 3 \\
\hline $76-80$ & 0 & 1 & 0 \\
\hline $81-85$ & 1 & 0 & 0 \\
\hline $86-90$ & 2 & 0 & 0 \\
\hline $\begin{array}{l}91-95 \\
96-\end{array}$ & 0 & 0 & 0 \\
\hline 100 & 0 & 0 & 0 \\
\hline Mean & 65.48 & 59.95 & 62.16 \\
\hline Modus & 65.00 & 59.25 & 59.30 \\
\hline $\begin{array}{l}\text { Media } \\
\text { n }\end{array}$ & 65.00 & 59.25 & 60.80 \\
\hline MIN & $\mathbf{5 7 . 5 0}$ & 51.00 & 56.60 \\
\hline MAX & 87.50 & 79.25 & 73.55 \\
\hline
\end{tabular}

Pelaksanaan pembelajaran siklus II digunakan langkah pembelajaran berikut: (a) pengarahan penggunaan modul dan penentuan materi; (b) pembentukan kelompok diskusi sesuai urutan presensi siswa; (c) pemberian motivasi dan contoh pekerjaan CAD di industri; (d) pemberian soal latihan yang menantang pengetahuan siswa untuk berkembang; (e) mengerjakan latihan bersama kelompok dengan sumber materi dari modul (f) Berdiskusi dengan kelompok terkait permasalahan yang dihadapi dan menemukan solusinya bersama; (g) membuka sesi tanya jawab dan refleksi; (h) melaksanakan penilaian autentik.

Hasil penilaian pekerjaan siswa menunjukkan peningkatan dari siklus I. Meskipun hasil menunjukkan peningkatan, 
namun peneliti melihat bahwa hasil tersebut masih memungkinkan untuk ditingkatkan lagi. Hasil penilaian siklus II dapat dilihat pada Tabel 2.

Tabel 2. Hasil Penilaian Pekerjaan Siswa Siklus II

\begin{tabular}{lrrr}
\hline & \multicolumn{3}{c}{ Frekuensi } \\
\cline { 2 - 4 } Nilai & $\begin{array}{c}\text { Modifikasi } \\
\text { Model 3D }\end{array}$ & $\begin{array}{c}\text { Penyajian } \\
\text { Gambar } \\
\text { 2D }\end{array}$ & $\begin{array}{c}\text { Kompetensi } \\
\text { CAD }\end{array}$ \\
\hline$\leq 60$ & 0 & 1 & 0 \\
$61-65$ & 0 & 0 & 1 \\
$66-70$ & 1 & 0 & 0 \\
$71-75$ & 1 & 5 & 2 \\
$76-80$ & 12 & 4 & 4 \\
$81-85$ & 2 & 8 & 8 \\
$86-90$ & 2 & 6 & 9 \\
$91-95$ & 7 & 2 & 1 \\
$96-100$ & 1 & 0 & 1 \\
\hline Mean & $\mathbf{8 5 . 0 0}$ & $\mathbf{8 1 . 1 4}$ & $\mathbf{8 2 . 6 9}$ \\
\hline Modus & $\mathbf{8 0 . 0 0}$ & $\mathbf{8 3 . 0 0}$ & $\mathbf{8 2 . 5 5}$ \\
\hline Median & $\mathbf{8 0 . 0 0}$ & $\mathbf{8 3 . 0 0}$ & $\mathbf{8 3 . 9 0}$ \\
\hline MIN & $\mathbf{7 0 . 0 0}$ & $\mathbf{5 2 . 2 5}$ & $\mathbf{6 2 . 3 5}$ \\
\hline MAX & $\mathbf{1 0 0 . 0 0}$ & $\mathbf{9 5 . 0 0}$ & $\mathbf{9 6 . 2 5}$ \\
\hline
\end{tabular}

Pelaksanaan pembelajaran siklus II digunakan langkah pembelajaran berikut: (a) pengarahan penggunaan modul dan penentuan materi; (b) Pembentukan kelompok diskusi disesuaikan dengan tingkat keahlian siswa.; (c) memberikan motivasi dan contoh hasil pekerjaan gambar yang telah dilakukan di industri; (d) Pemberian soal latihan yang menantang pengetahuan siswa untuk lebih berkembang; (e) Mengerjakan latihan dengan kelompok masing-masing dengan materi bersumber dari modul; (f) Berdiskusi dengan kelompok terkait permasalahan yang dihadapi dan menemukan solusinya bersama; (g) Membuka sesi tanya jawab dan penyampaian hasil diskusi sebagai sarana refleksi pembelajaran; (h) melaksanakan penilaian autentik.

Hasil penilaian pekerjaan siswa menunjukkan sedikit penurunan pada kompetensi CAD dari siklus II. Meskipun hasil penilaian menunjukkan penurunan, namun tingkat kelulusan siswa menunjukkan peningkatan. Hasil penilaian siklus III dapat dilihat pada Tabel 3 .

Tabel 3. Hasil Penilaian Pekerjaan Siswa Siklus III

\begin{tabular}{lrrr}
\hline \multirow{2}{*}{ Nilai } & \multicolumn{3}{c}{ Frekuensi } \\
\cline { 2 - 4 } & $\begin{array}{c}\text { Modifikasi } \\
\text { Model 3D }\end{array}$ & $\begin{array}{c}\text { Penyajian } \\
\text { Gambar 2D }\end{array}$ & $\begin{array}{c}\text { Kompetensi } \\
\text { CAD }\end{array}$ \\
\hline$\leq 60$ & 0 & 0 & 0 \\
$61-65$ & 0 & 0 & 0 \\
$66-70$ & 0 & 0 & 0 \\
$71-75$ & 0 & 4 & 0 \\
$76-80$ & 15 & 13 & 13 \\
$81-85$ & 6 & 5 & 10 \\
$86-90$ & 2 & 3 & 0 \\
$91-95$ & 3 & 1 & 3 \\
$96-$ & 0 & 0 & 0 \\
100 & $\mathbf{8 2 . 8 8}$ & $\mathbf{7 9 . 2 7}$ & $\mathbf{8 0 . 7 2}$ \\
\hline Mean & $\mathbf{8 0 . 0 0}$ & $\mathbf{7 5 . 5 0}$ & $\mathbf{7 8 . 0 5}$ \\
\hline Modus & $\mathbf{8 0 . 0 0}$ & $\mathbf{7 7 . 5 0}$ & $\mathbf{8 0 . 0 3}$ \\
\hline Median & $\mathbf{7 7 . 5 0}$ & $\mathbf{7 3 . 0 0}$ & $\mathbf{7 6 . 3 0}$ \\
\hline MIN & $\mathbf{9 5 . 0 0}$ & $\mathbf{9 0 . 5 0}$ & $\mathbf{9 2 . 3 0}$ \\
\hline MAX & & & \\
\hline
\end{tabular}

Pelaksanaan pembelajaran modul dengan pendekatan CTL yang dilaksanakan didapatkan hasil bahwa penerapan modul dengan pendekatan CTL dapat meningkatkan kompetensi siswa. Namun peningkatan tersebut melalui beberapa tahapan pada tiap siklusnya. Hasil akhir dari penerapan tersebut berupa kerangka pelaksanaan pembelajaran modul dengan pendekatan CTL sebagai berikut: (a) pengarahan penggunaan modul dan penentuan materi, (b) Pembentukan kelompok diskusi disesuaikan dengan tingkat keahlian siswa. (c) memberikan motivasi dan contoh hasil pekerjaan gambar yang telah dilakukan di industry, (d) Pemberian soal latihan yang menantang pengetahuan siswa untuk lebih berkembang, (e) Mengerjakan latihan dengan kelompok masing-masing dengan materi bersumber dari modul, (f) Berdiskusi dengan kelompok terkait permasalahan yang dihadapi dan menemukan solusinya bersama, (g) Membuka sesi tanya jawab dan penyampaian hasil diskusi sebagai sarana refleksi 
pembelajaran, (h) melaksanakan penilaian autentik.

Hasil penilaian yang didapatkan pada pelaksanaan pembelajaran CAD siklus I sampai III menunjukkan adanya peningkatan nilai kompetensi dari siklus I ke siklus II dan mengalami penurunan di siklus III. Rata-rata nilai kompetensi pada siklus I yaitu 62.16 meningkat menjadi 82.69 pada siklus II kemudian menurun menjadi 80.68 pada siklus III. Nilai kompetensi merupakan gabungan dari nilai modifikasi gambar 3D dan pembuatan gambar kerja dengan perbandingan $40 \%$ dan $60 \%$.

Hasil modifikasi gambar 3D, siswa menunjukkan peningkatan yang cukup baik pada tiap siklusnya. Pada siklus I rata-rata nilai modifikasi siswa adalah 65.48 kemudian menjadi 85 pada siklus II dan 82.79 pada siklus III. Sementara pada nilai penyajian gambar, nilai rata-rata yang didapatkan tidak sebaik modifikasi gambar 3D. Nilai penyajian gambar pada siklus I adalah 59.95 kemudian menjadi 81.14 pada siklus II dan 79.27 pada siklus III. Grafik perbandingan rata-rata nilai CAD dapat dilihat pada Gambar 1.

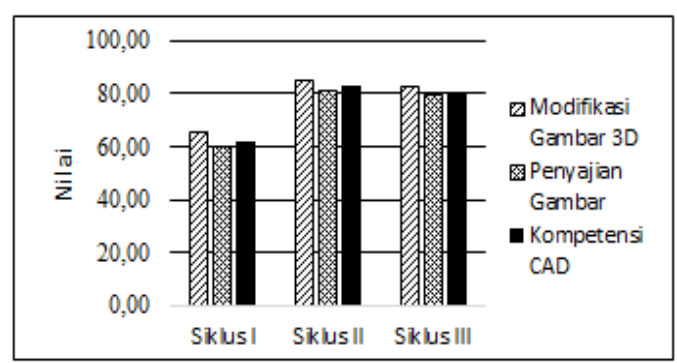

Gambar 1. Grafik Peningkatan Rata-rata Nilai Tiap Siklus

Sedangkan kelulusan siswa terhadap nilai KKM berdasarkan nilai kompetensi siswa terus mengalami peningkatan dari siklus I dengan kelulusan $0 \%$ kemudian menjadi $84.62 \%$ pada siklus II dan meningkat lagi menjadi $100 \%$ pada siklus III. Sedangkan pada subkompetensi modifikasi gambar 3D, tingkat kelulusannya juga terus mengalami peningkatan yaitu $11.54 \%$ pada siklus I kemudian $92.31 \%$ pada siklus II dan $100 \%$ pada siklus III.
Sementara pada sub-kompetensi penyajian gambar, tingkat kelulusan siswa belum terlalu baik yaitu $3.85 \%$ pada siklus I kemudian $76.92 \%$ pada siklus II dan $65.38 \%$ pada siklus III. Grafik persentase kelulusan siswa terhadap nilai KKM dapat dilihat pada Gambar 2.

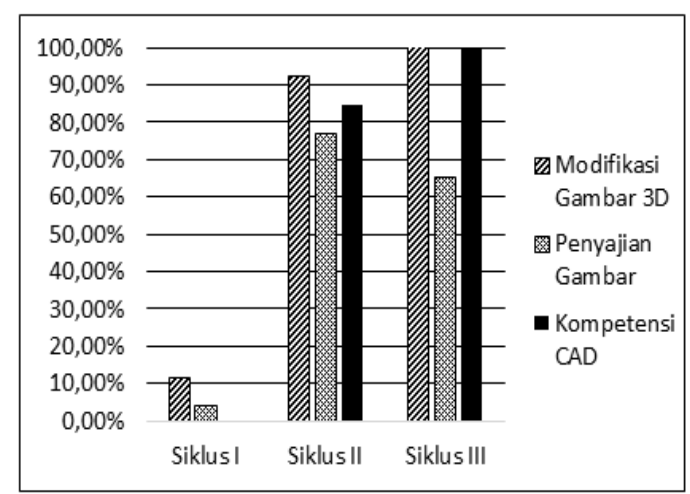

Gambar 2. Grafik Persentase Kelulusan Siswa Terhadap Nilai KKM

\section{SIMPULAN}

Hasil penelitian didapatkan bentuk pendekatan CTL yang diterapkan pada mata diklat CAD adalah (a) pengarahan penggunaan modul dan penentuan materi yang akan dipelajari (b) pembentukan kelompok diskusi disesuaikan dengan tingkat keahlian siswa (learning community) (c) pemberian motivasi dan contoh hasil pekerjaan gambar yang telah dilakukan di industry (modeling) (d) pemberian soal latihan yang menantang pengetahuan siswa untuk lebih berkembang (questioning) (e) mengerjakan latihan dengan kelompok masingmasing dengan materi bersumber dari modul (constructivism) (f) berdiskusi dengan kelompok terkait permasalahan yang dihadapi dan menemukan solusinya bersama (inquiry) (g) membuka sesi tanya jawab dan penyampaian hasil diskusi sebagai sarana refleksi pembelajaran (reflection) (h) melaksanakan penilaian sebenarnya dalam evaluasi (authentic assesment).

Hasil penilaian pekerjaan siswa menunjukkan adanya peningkatan nilai kompetensi dari siklus I dengan nilai kompetensi rata-rata 62.16 kelulusan siswa $0 \%$ ke siklus II dengan nilai kompetensi rata-rata 
82.69 kelulusan siswa $84.62 \%$. Sedangkan pada siklus III mengalami penurunan nilai rata-rata kompetensi dari siklus II 82.69 menjadi 80.68 pada siklus III, namun dari segi tingkat kelulusan siswa meningkat dari $84.62 \%$ menjadi $100 \%$.

\section{DAFTAR RUJUKAN}

Akhmad Adib Setyawan. (2014). Peningkatan Aktivitas dan Prestasi Belajar Siswa Pada Mata Pelajaran Gambar Teknik Mesin dengan Metode Contextual Teaching and Learning (CTL) di SMK Muhammadiyah 2 Borobudur. Skripsi Sarjana. Tidak diterbitkan. Universitas Negeri Yogyakarta. Yogyakarta.

Dionysius Dwi Noviantoro. (2014). Penerapan Model Pembelajaran Kontekstual untuk Meningkatkan Prestasi Belajar Siswa pada Mata Pelajaran Membaca Gambar Teknik di SMK Piri 1 Yogyakarta. Skripsi Sarjana. Tidak diterbitkan. Universitas Negeri Yogyakarta. Yogyakarta.

Johnson, E.B. (2014). Contextual Teaching and Learning: Menjadikan Kegiatan BelajarMengajar Mengasyikkan dan Bermakna. Penerjemah: Ibnu Setiawan. Bandung: Kaifa.
Madsen, David A. \& Madsen, David P. (2012). Engineering Drawing and Design. $5^{\text {th }}$. ed. New York: Delmar Cengage Learning.

Paizaluddin \& Ermalinda. (2014). Penelitian Tindakan Kelas (Classroom Action Research): Panduan Teoritis dan Praktis. Bandung: Alfabeta.

Smaldino, Sharon E., Lowther, Deborah L., \& Russel, James D. (2012). Instructional Technology and Media for Learning (Teknologi Pembelajaran dan Media untuk Belajar). Penerjemah: Arif Rahman. Jakarta: Kencana.

Suharsimi Arikunto, Suhardjono, \& Supardi. (2015). Penelitian Tindakan Kelas. rev. ed. Jakarta: PT. Bumi Aksara.

Xin-Ran Duan. (2004). A Model Curriculum for Computer Aided Design (CAD) Associate Degree Programs. Journal of Industrial Technology, 20 (2), Hlm. 5-6. 